\title{
Immunoexpression of TTF-1 in Non-Lung Tumors
}

\author{
Akciğer Dışındaki Tümörlerde İmmunhistokimyasal TTF-1 \\ Ekspresyonu
}

\author{
Zeynep TOSUNER, Dilek Sema ARICI, Zühal GÜCIN, Nur BÜYÜKPINARBAŞILI, Fatma Cavide SÖNMEZ, \\ Pelin YILDIZ \\ Department of Pathology, Bezmialem Vakif University, Faculty of Medicine, Istanbul, Turkey
}

\section{ABSTRACT}

Objective: Thyroid transcription factor-1 (TTF-1) immunoexpression is frequently determined in small-cell lung carcinomas, as well as primary lung adenocarcinomas. While dealing with metastatic carcinomas, TTF-1 immunoexpression is a significant indicator of primary lung carcinomas. Recent studies have revealed that TTF1 immunoexpression is also defined in non-lung cancers, such as squamous cell carcinomas of different sites and certain neuroendocrine tumors. The verified data obtained from these studies indicate that a straightforward diagnosis of primary lung carcinoma in cases with positive TTF-1 immunoexpression can cause diagnostic contradictions. The aim of our study is to investigate the immunoexpression status of TTF-1 in common non-lung tumors.

Methods: A total of 85 cases that were diagnosed in our institute between the years 2011-2012 were included in our study. After a review of the pathological slides prepared from these tumors [colon adenocarcinoma (n: 15), renal cell carcinoma (n: 15), prostate adenocarcinoma (n: 15), invasive papillary urothelial carcinoma (n: 15), invasive ductal carcinoma of breast (n: 15), and neuroendocrine tumors (n: 10)] TTF-1 immunohistochemistry was applied. Semiquantative evaluation based on the distribution and intensity of the staining was performed by two pathologists, respectively.

Results: Positive immunostaining was evident in only 1 case of colon adenocarcinoma out of 85 cases.

Conclusion: Our study demonstrated that TTF-1 immunoexpression is a very rare finding $(1 \%)$ in non-lung tumors. This result provides that anti-TTF-1 is a reliable antibody in the interpretation of primary lung carcinomas. In fact, further studies with a large number of cases are needed to confirm the sensitivity and specificity of TTF-1.

Key Words: TTF-1, immunohistochemistry, non-lung tumors

\section{ÖZET}

Amaç: Akciğerin küçük hücreli karsinomu ve adenokarsinomunda Tiroid transkripsiyon faktörü-1 (TTF-1) immunekspresyonu sıklıkla görülür. Bu nedenle metastatik karsinomlarının değerlendirilmesinde patolojik incelemede TTF-1 antikoru rutin uygulamada oldukça yararlıdır. Son yıllarda akciğer dışı skuamöz hücreli karsinomda ve bazı nöroendokrin tümörlerde de TTF-1 immunekspresyonu görülebildiği bildirilmiştir. $\mathrm{Bu}$ durum tanıda sıkıntılara sebep olabilmektedir. Çalışmamızın amacı, sık görülen akciğer dışı tümörlerde TTF-1 immunekspresyonunun değerlendirilmesidir.

Yöntemler: Üniversitemizde 2011-2012 yılları arasında tanı almış olan 15 'er adet kolon adenokarsinomu, renal hücreli karsinom, prostat adenokarsinomu, invaziv papiller urotelial karsinom, memenin invaziv duktal karsinom ve 10 adet nöroendokrin tümöre olmak üzere 85 adet tümöre ait lamlar yeniden değerlendirilmiş ve tümörlere TTF-1 uygulanmıştır. Tümör hücrelerinde boyanma şiddeti ve yoğunluğu iki patolog tarafindan semikantitatif olarak değerlendirilmiştir.

Bulgular: Çalışma kapsamına alınan 85 olgudan sadece bir kolon adenokarsinomunda şiddetli TTF-1 immunekspresyonu görülmüştür. Diğer olgularda ise anlamlı boyanma gözlenmemiştir.

Sonuç: Çalışmamızda sık görülen akciğer dışı tümörlerden sadece bir olguda TTF-1 immunekspresyonu görülmesi (\%1) TTF1 'in primer akciğer karsinomlarının değerlendirilmesinde güvenilir bir antikor olduğunu desteklemektedir. Ancak bu antikorun duyarlılığının ve özgüllüğünün tam olarak anlaşılması açısından daha geniş kapsamlı serilerin incelenmesi yararlı olacaktır.

Anahtar Sözcükler: TTF-1, immünhistokimya, akciğer dışı tümörler 


\begin{tabular}{|c|c|c|}
\hline Tümör tipi & $\begin{array}{c}\text { Olgu } \\
\text { sayısı (n) }\end{array}$ & $\begin{array}{c}\text { TTF-1 } \\
\text { immunekspresyonu (n) }\end{array}$ \\
\hline Kolon adenokarsinomu & 15 & 1 \\
\hline Prostat adenokarsinomu & 15 & 0 \\
\hline Papiller urotelial karsinom & 15 & 0 \\
\hline İnvaziv duktal karsinom & 15 & 0 \\
\hline Renal hücreli karsinom & 15 & 0 \\
\hline Nöroendokrin tümör & 10 & 0 \\
\hline *n: sayı & & \\
\hline
\end{tabular}

\section{Giriş}

Tiroid transkripsiyon faktör-1 (TTF-1) ekspresyonu tiroidde, akciğerde tip II pnömositlerde ve Clara hücrelerinde ve beynin bazı bölgelerinde görülür (1). Akciğerin küçük hücreli karsinomu yanı sıra adenokarsinomunda TTF-1 ekspresyonu olduğu, skuamöz hücreli karsinomu ile nöroendokrin tümörlerde ise ekspresyon görülmediği bilinmektedir (2). $\mathrm{Bu}$ nedenle TTF-1 immünekspresyonu metastatik adenokarsinomların primerini belirlemede tanıya yardımcı olarak kullanılmaktadır (3). Akciğerin küçük hücreli karsinomunu diğer küçük hücreli karsinomlardan ayırt etmekte kullanılabileceği yönünde bir çalışma literatürde yer almıştır (4). Ancak son yıllarda mesanenin küçük hücreli karsinomunda ve çeşitli nöroendokrin tümörlerde, akciğer dışı skuamöz hücreli karsinomlarda da değişen oranda TTF-1 ekspresyonu görülebildiğine dair çalışmalar mevcuttur (5-6). Çalışmamızın amacı akciğer dışındaki çeşitli sık görülen tümörlerde TTF-1 immünekspresyonunun değerlendirilmesidir.

\section{Yöntemler}

2011-2012 yılları arasında üniversitemizde tanı alan toplam 85 adet akciğer dışı tümör çalışma kapsamına alınmıştır. Onbeş'er adet kolon adenokarsinomu, berrak hücreli tipte renal hücreli karsinom, prostat adenokarsinomu, invaziv papiller urotelial karsinom, memenin invaziv duktal karsinomu ve 10 adet nöroendokrin tümöre ait lamlar yeniden değerlendirilmiş ve tümörlere TTF-1 uygulanmıştır (Tablo 1). Nöroendokrin tümörlerden 8 tanesi apendiks kaynaklı nöroendokrin tümör, 2 tanesi ise mesanenin küçük hücreli karsinomu tanısı almıştır. Tümör hücrelerinin \%5'inden fazlasında boyanma pozitif boyanma olarak kabul edilmiş olup boyanma şiddeti zayıf $(1+)$, orta $(2+)$ ve şiddetli (3+) olarak değerlendirilmiştir. Olguların immunekspresyon düzeyleri iki patolog tarafından yorumlanmıştır.

\section{Bulgular}

Çalışma kapsamına alınan toplam 85 olgudan yalnızca bir tanesinde anlamlı pozitif TTF-1 ekspresyonu görülmüştür. Pozitif olgu kolon adenokarsinomuna aittir (Resim 1). Ne-

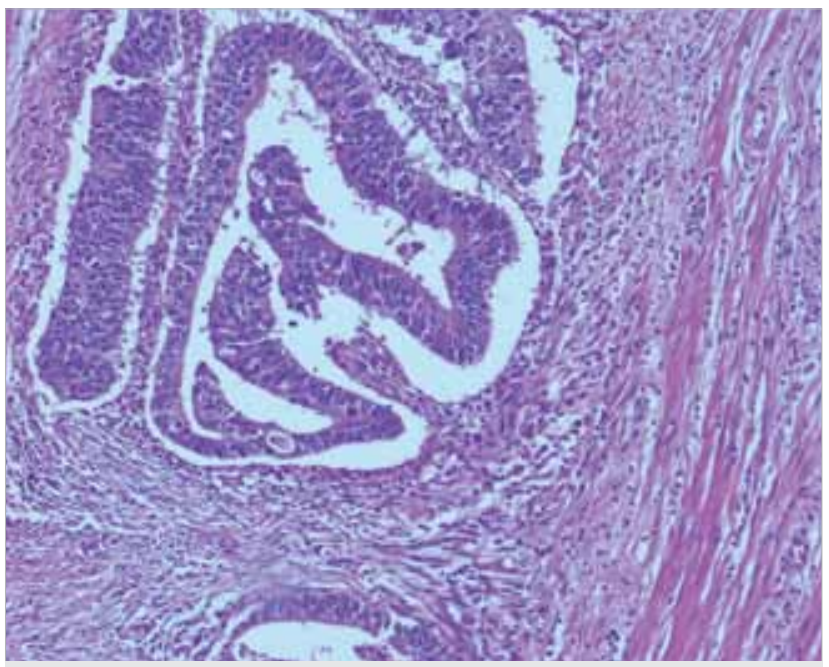

Resim 1. Kolon adenokarsinomu, boyanma yok, H-E x100

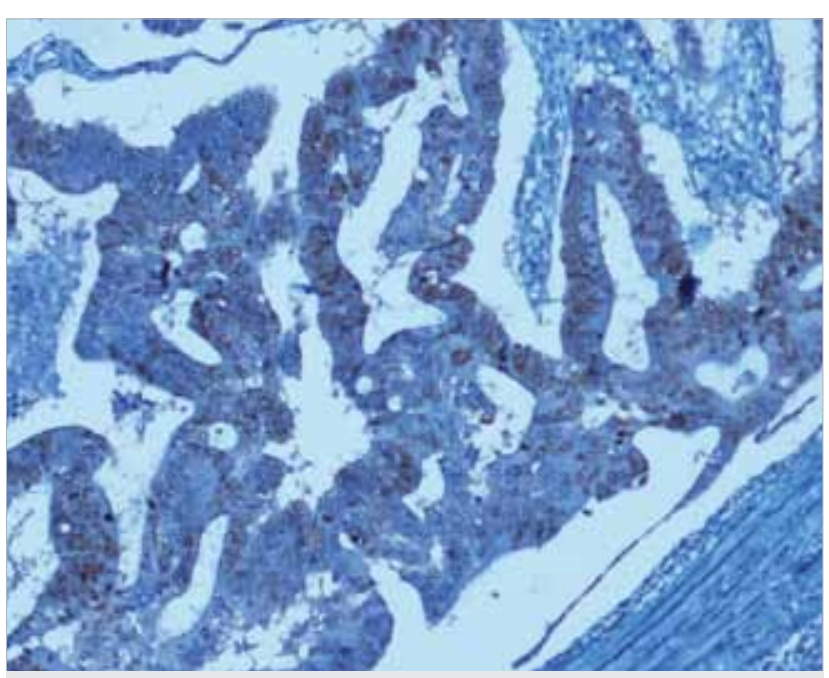

Resim 2. TTF-1 ile diffuz kuvvetli nükleer immunekspresyon varlığı, x100

ekspresyonu izlenmiştir (Resim 2). Bir apendiks kaynaklı nöroendokrin tümör ve bir kolon adenokarsinomunda $\% 5$ 'ten az oranda neoplastik hücrede immünekspresyon saptanmış ancak bu olgular negatif olarak yorumlanmıştır.

\section{Tartışma}

TTF-1, tiroid ve akciğer orijinli tümörleri belirlemede kullanılan bir immunohistokimyasal belirleyicidir. Uzun yıllardır patoloji pratiğinde primer akciğer karsinomlarının tanısında sıklıkla kullanılmakta olan bir antikordur. Ancak son yıllarda yapılan çeşitli araştırmalarda akciğer dışı karsinomlarda da değişen oranda TTF-1 immünekspresyonunun görülebildiği, bu durumun metastatik karsinomların akciğer kaynaklı olup olmadığının ayırt edilebilmesinde zorluğa neden olduğu bildirilmektedir (4-6). Ayrıca TTF-1'in farklı klonları ile de sonuçların farklı olabileceği ekspresyonların farklı şiddette olabileceği bildirilmiştir (7). Bu nedenlerle TTF-1'in tanı aşamasında kullanılmasının sorgulanması söz konusu olmuştur. Mesanenin yüksek grade'li karsinomu ile ilgili yapılan bir 
çalışmada TTF-1 ekspresyonunun aberran olabileceği kabul edilmiş ve tanısal zorluğa neden olduğu vurgulanmıştır (8). Tüm bu sonuçlar ve görüşlere karşın TTF-1'in akciğer ve tiroid orijinli tümörlerin tanısında önemli olduğu ve immun panellerde mutlaka bulunması gerekliliği de belirtilmiştir (3).

Çalışmamız kapsamına altı organa (kolon, mesane, prostat, böbrek, meme, apendiks) kaynaklı sık görülen (adenokarsinom, nöroendokrin tümör) tümörler alınmıştır. Daha geniş bir örneklem yapılması ve diğer organ ve sistemlere ait neoplazilerde TTF-1 immunekspresyonunun belirlenmesi çalışmanın duyarlılığını arttırabilir. Yalnızca bir olguda anlamlı boyanma izlenmesi nedeniyle spesifik istatistiksel çalışma yapılmamış, pozitif immunekspresyon oranı (\%1) olarak belirtilmiştir.

\section{Sonuç}

Çalışmamızda oldukça az sayıda olguda immunekspresyon görülmesi ve sadece bir olguda anlamlı pozitiflik olmsı TTF1 'in güvenilir bir antikor olduğunu desteklemiş olmakla birlikte TTF-1'in duyarlılığının ve özgüllüğünün tam olarak değerlendirilmesi için daha çok sayıda ve türde tümörün immünhistokimyasal ve moleküler olarak incelenmesi kesin sonuçlar elde etmede yardımcı olacaktır.

Ethics Committee Approval: Ethics committee approval was not received due to the retrospective nature of the study.

Informed Consent: Informed consent was not obtained due to the retrospective nature of this study.

Peer-review: Externally peer-reviewed.

Author Contributions: Concept - Z.T., D.S.A.; Design - Z.T., D.S.A.; Supervision - P.Y., C.S.; Funding - C.S., N.B. Materials - Z.G., P.Y. Data Collection and/or Processing - Z.T.; Analysis and/or Interpretation - Z.T., D.S.A.; Literature Review - Z.T.; Writing - Z.T.; Critical Review - C.S., D.S.A.

Conflict of Interest: No conflict of interest was declared by the authors.

Financial Disclosure: The authors declared that this study has received no financial support.
Etik Komite Onayı: Çalışmanın retrospektif tasarımından dolayı etik komite onayı alınmamıștır.

Hasta Onamı: Çalışmanın retrospektif tasarımından dolayı hasta onamı alınmamıştır.

Hakem Değerlendirmesi: Dış bağımsız

Yazar Katkıları: Fikir - Z.T, D.S.A.Tasarım - Z.T., D.S.A; Denetleme P.Y.,C.S. ; Kaynaklar - C.S, N.B.; Malzemeler - Z.G.,P.Y.; Veri Toplanması ve/veya İşlemesi - Z.T.; Analiz ve/veya Yorum - Z.T,D.S.A; Literatür Taraması - Z.T.; Yazıyı Yazan - Z.T. ; Eleştirel İnceleme - C.S, D.S.A.

Çıkar Çatışması: Yazarlar çıkar çatışması bildirmemişlerdir.

Finansal Destek: Yazarlar bu çalışma için finans destek almadıklarını beyan etmişlerdir.

\section{Kaynaklar}

1. Lau SK, Luthringer DJ, Eisen RN. Thyroid transcription factor-1: a review. Appl Immunohistochem Mol Morphol 2002; 10: 97-102. [CrossRef]

2. Ordóñez NG. Thyroid transcription factor- 1 is a marker of lung and thyroid carcinomas. Adv Anat Pathol 2000; 7: 123-7. [CrossRef]

3. Kaufmann O, Dietel M. Thyroid transcription factor 1 is the superior immunohistochemical marker for pulmonary adenocarcinomas and large cell carcinomas compared to surfactant proteins A and B. Histopathology 2000; 36: 8-16. [CrossRef]

4. Ordóńez NG. Value of thyroid transcription factor-1 immunostaining in distinguishing small cell carcinomas from other small cell carcinomas. Am J Surg Pathol 2000; 24: 1217-23. [CrossRef]

5. Cheuk W, Kwan MY, Suster S, Chan JK. Immunostaining for thyroid transcription factor 1 and cytokeratin 20 aids the distinction of small cell carcinoma from Merkel cell carcinoma, but not pulmonary from extrapulmonary small cell carcinomas. Arch Pathol Lab Med 2001; 125: 228-31.

6. Alijo Serrano F, Sánchez-Mora N, Angel Arranz J, Hernández C, Álvarez-Fernández E. Large cell and small cell neuroendocrine bladder carcinoma: immunohistochemical and outcome study in a single institution. Am J Clin Pathol 2007; 128: 733-9. [CrossRef]

7. Matoso A, Singh K, Jakob R, Greaves WO, Traveres R, Noble L, et al. Comparison of thyroid transcription factor- 1 expression by 2 monoclonal antibodies in pulmonary and nonpulmonary primary tumors. Appl Immunohistochem Mol Morphol 2010; 18: 142-9. [CrossRef]

8. Fernandez-Acenero MJ, Cordova S, Santonja C. Aberrant TTF-1 expression in papillary high-grade urothelial neoplasm: Case Report and Literature Review. Rom J Morphol Embryol 2011; 52: $171-4$. 